\title{
Investigating Effects Of Carbonate Minerals On Shale- Hydraulic Fracturing Fluid Interactions In The Marcellus Shale
}

\author{
Brennan Matthew Ferguson \\ bmf0025@mix.wvu.edu
}

Follow this and additional works at: https://researchrepository.wvu.edu/etd

Part of the Geochemistry Commons

\section{Recommended Citation}

Ferguson, Brennan Matthew, "Investigating Effects Of Carbonate Minerals On Shale- Hydraulic Fracturing Fluid Interactions In The Marcellus Shale" (2020). Graduate Theses, Dissertations, and Problem Reports. 7766.

https://researchrepository.wvu.edu/etd/7766

This Thesis is protected by copyright and/or related rights. It has been brought to you by the The Research Repository @ WVU with permission from the rights-holder(s). You are free to use this Thesis in any way that is permitted by the copyright and related rights legislation that applies to your use. For other uses you must obtain permission from the rights-holder(s) directly, unless additional rights are indicated by a Creative Commons license in the record and/ or on the work itself. This Thesis has been accepted for inclusion in WVU Graduate Theses, Dissertations, and Problem Reports collection by an authorized administrator of The Research Repository @ WVU. For more information, please contact researchrepository@mail.wvu.edu. 


\title{
INVESTIGATING EFFECTS OF CARBONATE MINERALS ON SHALE- HYDRAULIC FRACTURING FLUID INTERACTIONS IN THE MARCELLUS SHALE
}

\author{
Brennan Ferguson
}

\author{
Thesis Submitted to: \\ The Eberly College of Arts and Sciences \\ West Virginia University \\ In partial fulfillment of the requirements for the degree of \\ Master of Science in Geology \\ Shikha Sharma, Ph.D., Chair \\ Vikas Agrawal, Ph.D. \\ Alexandra Hakala, Ph.D. \\ Timothy Carr, Ph.D.
}

Department of Geology and Geography

Morgantown, WV

2020

Key Words: Hydraulic Fracturing, Geochemistry, Carbonates, Natural Gas

Copyright 2020 Brennan Ferguson 


\begin{abstract}
INVESTIGATING EFFECTS OF CARBONATE MINERALS ON SHALE- HYDRAULIC FRACTURING FLUID INTERACTIONS IN THE MARCELLUS SHALE
\end{abstract} Brennan Ferguson

\begin{abstract}
Natural gas extracted from tight shale formations, such as the Marcellus Shale, represent an important and developing front in energy exploration. By fracturing these formations using pressurized fracturing fluid, previously unobtainable hydrocarbon reserves may be tapped. While pursuing this resource hydraulic fracturing operations leave chemically complex fluids in the shale formation for at least two weeks. This provides a substantial opportunity for the hydraulic fracturing fluid (HFF) to react with the shale formation at reservoir temperature and pressure. In this study we investigated the effects of the carbonates on shale-HFF reactions with a focus on the Marcellus Shale. We determined the effects of carbonate minerals on shale-HFF reactions by performing autoclave experiments at high reservoir temperature and pressure conditions using a carbonate rich and carbonate free shale sample. We observed that carbonate minerals not only directly controlled the $\mathrm{pH}$ of the solution but also had a range of secondary effects on oxidizing efficacy of breakers, iron controlling ability of citric acid, mineral dissolution, and organic matter oxidation. As a consequence, the carbonate minerals had a broad influence on shale-HFF interactions. These interactions can potentially affect the shale porosity, the well's microfracture integrity, and the release of heavy metals and volatile organic contaminants in the produced water released on the surface.
\end{abstract}




\section{Table of Contents}

List of Figures

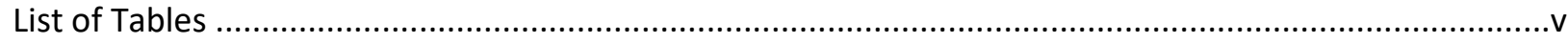

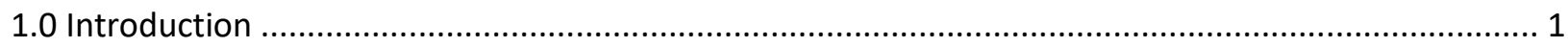

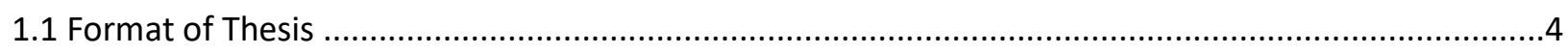

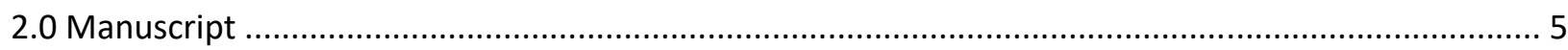

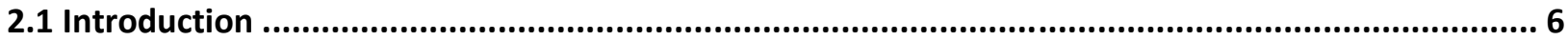

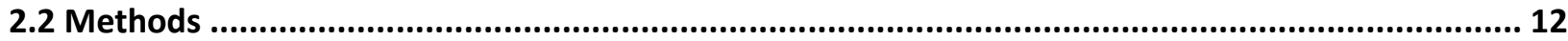

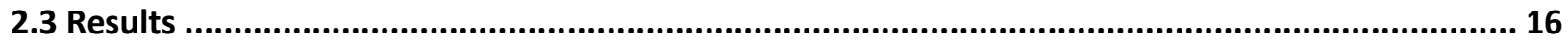

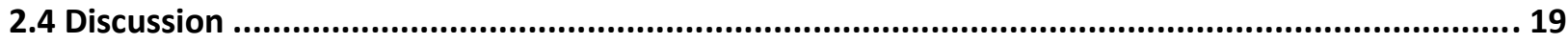

2.5 Conclusions

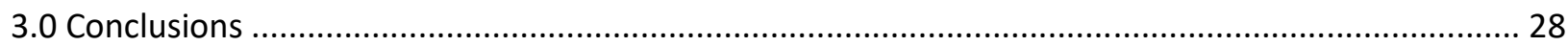

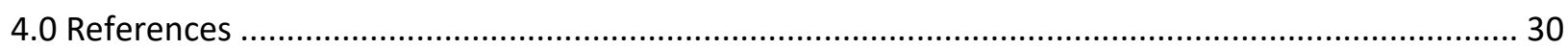

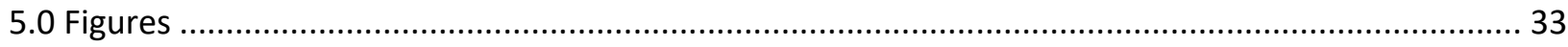

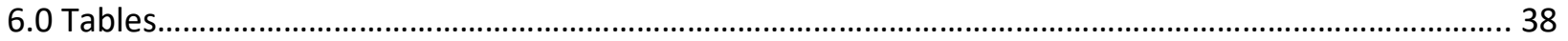




\section{List of Figures}

Figure 1-Dry shale gas production in the United States by formation (U.S. EIA, 2019) 33

Figure 2-Post-reaction $\mathrm{pH}$ for each sample vs $\mathrm{pH}$ measured immediately before reaction. 33

Figure 3-Metals in solution released from reactions with shale. HFF serves as a control for contaminants in additives, reactor corrosion ( $\mathrm{Fe}$ ), and instrument error.

Figure 4-SEM and SEM-EDS images of reacted SH-HFF and SH-HFF (-CO3) shale chips. The sulfur and iron dense areas detected by EDS are presumed to be pyrite.

Figure 5-BTEX in solution for each reaction by $G C-M S$.

Figure 6-Aluminum in solution plotted against $\mathrm{pH}$ to highlight the role of $\mathrm{pH}$ in aluminum dissolution from clay minerals.

Figure 7-Metals associated with pyrite in solution plotted against total citrate in solution to highlight citric acid's roll in pyrite dissolution.

Figure 8-Citrate plotted against pH demonstrating the pH dependency of calcium citrate. 36

Figure 9- The change in $\mathrm{pH}$ due to carbonate dissolution plotted with DIC.

Figure 10-Barium and sulfate ions in solution indicating limiting reagent or barite precipitation. Cadmium is plotted as a proxy for pyrite dissolution vs sulfate in solution. 


\section{List of Tables}

Table 1 - LM-2 shale mineral composition, depth and organic content description (Pilewski et al., 2019).

Table 2 - Fracturing fluid additives and brine salts used to make the synthetic fracturing fluid mixture used in reactions.

Table 3-Tabulated pH, IC and ICP-MS fluid chemistry results for each reaction and unreacted fracturing fluid.

Table 4-BTEX in solution from GC-MS analysis with detection and quantification limits.

40 


\subsection{Introduction}

\section{Hydraulic Fracturing}

The use of hydraulic fracturing to extract natural gas from shale reservoirs has become a widespread practice and a considerable part of America's energy portfolio since the mid-to-late 2000s (U.S. EIA, 2017). The Marcellus Shale is one of the major shale reservoirs that has been exploited in this boom, making fracturing an enormously important industry to West Virginia and the Appalachian.

Hydraulic fracturing, often referred to as fracking, is a process that allows energy resources to be extracted from impermeable shale by opening cracks in the formation with hydraulic pressure. The modern approach to this technique is extremely complex, with many stages. Several wells are drilled in close proximity to one. Once the vertical wells reach the target formation, they pivot and drill through the formation, creating much more area for the well to interact with the formation. This multitude of wells creates a wheel-spoke pattern in the gas bearing shale formation, and dramatically increases the yield of hydrocarbons from shale from what was available through conventional means (Arthur et al., 2009). At this point, approximately 4.25 million gallons of water per well is used to hydraulically fracture the Marcellus Shale with other formations varying (Kondash and Vengosh, 2015). The initial water is mixed with several chemicals, including hydrochloric acid, biocides, descaling agents, and friction reducers, all of which aid in creating fractures and maintaining the well. In order to prop open these fractures, silica granules called proppant are injected along with gelling agents to help push the proppant into place (PA DEP). This is followed by breaker chemicals including persulfates which break down the gelled water in order to pull it back out following a shut-in period of several days to weeks (Marcon et al., 2017). After this shut in period, a portion of this 
water and the natural brine in the formation totaling to 1.37 million gallons per well in the Marcellus Shale (Kondash and Vengosh, 2015) are pumped out in order to let gas escape.

The different hydrocarbon bearing shales generally have much in common but are also very distinct in terms of mineralogy and hydrocarbon make-up (Jew et al. 2017). The Marcellus Shale is the most productive shale formation for dry gas in the United States (EIA, 2019) and is extremely economically important to the region. However, even within the Marcellus Shale formation there is still a great deal of heterogeneity including total organic carbon, thermal maturity, and mineralogy (Pilewski et al., 2019; U.S. EIA, 2019). Due to these heterogeneities the chemical reactions taking place in hydraulically fractured fracture shale reservoirs can vary significantly spatially and temporally even within a single formation, which in turn influences the best choices for hydraulic fracturing fluid (HFF) components used at any given well site.

The chemical composition of HFF plays an important role in the overall hydrocarbon yield from the well. Generally, hydraulically fractured shale gas wells will initially produce very large amounts of gas that drops off rapidly as the well depressurizes. Additionally, the models based on gas pressure and the flow dynamics show much higher production over time than the actual production is higher, particularly towards the end of well's producing life (Jew et al. 2017). There could be multiple possible causes for this model discrepancy, but one of particular concern is the scaling of minerals in the shale fractures and pores. The addition of HFF to the formation triggers complex geochemical reactions in the subsurface. Among these changes are the dissolution and precipitation of various mineral phases such as barite $\left(\mathrm{BaSO}_{4}\right)($ Vankeuren et al. 2017) and various iron oxides (Jew et al., 2017). The interactions between the shale, formation brine, and HFF also affects the composition of the produced water that returns to the surface and the remediation needed for that water (Marcon et al. 2017). 


\section{Carbonate Minerals}

Calcite and dolomite make up the overwhelming majority of carbonate minerals in most tight gas shales. Their proportions within these shales varies greatly both between formations and within them from $58 \%$ by mass calcite with $12 \%$ dolomite in an Eagle Ford formation sample to $21 \%$ calcite with 5\% dolomite in the Marcellus Shale and calcite below detection limit with 4\% dolomite in a different Marcellus Shale sample. The amount of carbonates in the local formation a well is placed, is very important to the geochemistry of that well, because of carbonate mineral's ability to neutralize the acid. Calcite and dolomite react with acid, such as the $\mathrm{HCl}$ commonly included in HFF, to produce $\mathrm{Ca}^{+2}, \mathrm{Mg}^{+2}$ (in the case of dolomite), and $\mathrm{HCO}_{3}{ }^{-}$, which acts as a buffer for the system and controls the $\mathrm{pH}$ (Wang et al., 2015). This reaction has been shown to be independent of the redox conditions of the system (Wang et al., 2015; Wang et al., 2016). Evidence of this can be seen in the results of many experiments that show an increase in $\mathrm{Ca}, \mathrm{Mg}$, and dissolved inorganic carbon (DIC) proportionate to the amount of carbonate in the system (Wang et al., 2015; Pilewski et al., 2019). Additionally, the final $\mathrm{pH}$ of a reactions between shale and HFF or other acidic solutions is directly related to the carbonate content, showing the carbonate minerals ability to neutralize the acid in solution and maintain a much higher $\mathrm{pH}$ than lower carbonate content shales (Pilewski et al., 2019). The dissolution of carbonate minerals as a result of neutralizing acidity can also be seen as a change in mineralogy and elemental composition of the shale in XRD and ICP-MS (Wang et al., 2015; Marcon et al., 2017). This can have a desirable effect for gas extraction by increasing pore size which is particularly helpful to late stage production (Vankeuren et al., 2017). 


\subsection{Format of Thesis}

The first chapter of this thesis contains background information prepared in advance for this investigation. Chapter 2 is the manuscript created from this work for future submissions to a scientific journal. Chapter 3 provides the conclusions of this thesis and its implications. 


\title{
2.0 INVESTIGATING EFFECTS OF CARBONATE MINERALS ON SHALE- HYDRAULIC FRACTURING FLUID INTERACTIONS IN THE MARCELLUS SHALE
}

\begin{abstract}
Natural gas extracted from tight shale formations, such as the Marcellus Shale, represents a significant and developing front in energy exploration. By fracturing these formations using pressurized fracturing fluid, previously unobtainable hydrocarbon reserves may be tapped. While pursuing this resource, hydraulic fracturing operations leave chemically complex fluids in the shale formation for at least two weeks. This provides a substantial opportunity for the hydraulic fracturing fluid (HFF) to react with the shale formation at reservoir temperature and pressure. In this study, we investigated the effects of the carbonates on shale-HFF reactions with a focus on the Marcellus Shale. We determined the effects of carbonate minerals on shale-HFF by performing autoclave experiments at high reservoir temperature and pressure conditions using a carbonate rich shale sample and an identical carbonate free shale sample. We observed that carbonate minerals had a direct effect on the $\mathrm{pH}$ of the solution, as well as several secondary effects oxidizing efficacy of breakers, the iron controlling ability of citric acid, mineral dissolution, and organic matter oxidation. The broad influence of carbonate minerals on shaleHFF reactions can potentially affect the porosity of shale, microfracture integrity of the well, and the release of heavy metals and volatile organic contaminants in the produced water.
\end{abstract}




\subsection{Introduction}

The use of hydraulic fracturing to extract natural gas from shale reservoirs has become a widespread practice of considerable importance to America's energy portfolio since the shale gas boom began in the mid-to-late 2000s (U.S. EIA, 2017). The Marcellus Shale is one of the major shale reservoirs that has been utilized in this boom, making hydraulic fracturing an enormously important industry to West Virginia and the Appalachian region, as shown in Figure 1.

Hydraulic fracturing, often referred to as fracturing, is generically the fracturing of rocks around a wellbore in order to increase the permeability of the rock and therefore the flow of gas from it. Many wells are drilled in close proximity on a well pad and after reaching the depth of the target formation, such as the Marcellus Shale, the drill pivots to go horizontally into the formation. This multitude of wells creates a wheel-spoke pattern in the gas bearing shale formation, and dramatically increases the yield of hydrocarbons from shale compared to what was available through conventional means (Arthur and Layne, 2008). Approximately 4.25 million gallons of water per well are used to hydraulically fracture the Marcellus Shale with other formations varying (Kondash and Vengosh, 2015). The water is mixed with a variety of chemicals to create fractures and maintain the well. In order to prop open these fractures, silica granules called proppant are injected along with gelling agents to help push the proppant into place (PA DEP). This is followed by breaker chemicals, such as persulfates, which break down the gelled water in order to pull it back out following a shut-in period of several days to weeks (Marcon et al., 2017). After this shut in period, a portion of this water and the natural brine in the formation, totaling to 1.37 million gallons per well in the Marcellus Shale (Kondash and Vengosh, 2015), are pumped out in order to let gas escape. 
Hydrocarbon bearing shales generally have much in common but are distinct in terms of mineralogy and hydrocarbon make-up. The Marcellus Shale is the most productive shale formation for dry gas in the United States (U.S. EIA, 2019) and is extremely economically important to the region. However, within the Marcellus Shale Formation, there is still a great deal of heterogeneity, including total organic carbon content, type of organic matter, thermal maturity, and mineralogy (Pilewski et al., 2019; U.S. EIA, 2017). Because of this, the chemistry taking place inside hydraulically fractured shale gas wells varies between formations, which influences the selection of hydraulic fracturing fluid (HFF) components used at any given well site (Abualfaraj et al., 2014).

During hydraulic fracturing operations of horizontal wells, the mixture of water and chemical additives that comprise HFF are in contact with the target shale formation for a period of weeks to react with the brine and shale in the formation at high temperature and pressure. During this time, numerous interactions can take place that significantly alters HFF fluid chemistry, the mineral composition and petrophysical properties of shale, and release of organic and inorganic contaminants (Harrison et al., 2017; Paukert Vankeuren et al., 2017; Pilewski et al., 2019)). Studies conducted using bench top reactors have shown many shale-HFF reactions can take place such as mineral precipitation and dissolution, organo-metallic complex formation, ion adsorption onto shale organic matter and clay minerals, and organic matter degradation (Jew et al., 2017; Pilewski et al., 2019) . Among these, mineral dissolution and precipitation reactions impact the porosity and permeability of shale the most. Changes in flow dynamics from precipitation reactions have been implicated as a potential cause for discrepancies between modeled and actual late-stage hydrocarbon production in hydraulically fractured wells (Jew et al., 2017). Dissolution of shale minerals and organic matter degradation can increase the porosity 
and permeability of shale, but increases the toxicity of produced waters (Harrison et al., 2017; Armstrong et al., 2019), and the risks posed by spills. The dominant role that carbonate minerals play in controlling the $\mathrm{pH}$ during shale-HFF interactions significantly impacts all the reactions taking place in the reservoir and also affects the stability of all other reactive components. The Marcellus Shale has a variable composition of carbonate minerals with calcite $\left(\mathrm{CaCO}_{3}\right)$ ranging from $3-48 \%$ and dolomite $\left(\mathrm{CaMg}\left(\mathrm{CO}_{3}\right)_{2}\right)$ ranging from $0-10 \%$ as well as trace amounts of other carbonates such as siderite (U.S. EIA, 2017; Morsy et al., 2013). Carbonates react with acids in $\mathrm{HFF}$, such as $\mathrm{HCl}$, and release $\mathrm{Ca}^{+2}, \mathrm{Mg}^{+2}$ (in the case of dolomite), and $\mathrm{HCO}_{3}^{-}$. The reaction neutralizes acid through the formation of $\mathrm{HCO}_{3}{ }^{-}$, which further acts to buffer the chemical system and control the $\mathrm{pH}$ (Wang et al., 2015). This reaction between HFF and carbonate minerals is dependent on the $\mathrm{pH}$ of the system (Wang et al., 2015, 2016), which is primarily controlled by the carbonate content of the shale formation and acid added in the HFF. Previous work on shale-HFF interactions has demonstrated a strong relationship between increases in $\mathrm{pH}$, $\mathrm{Ca}, \mathrm{Mg}$, and dissolved inorganic carbon (DIC) proportionate to the amount of carbonate in the system (Wang et al., 2015; Pilewski et al., 2019). X-ray diffraction analysis demonstrated commensurate losses of the primary carbonate minerals in reservoir shales, calcite and dolomite, to the fluid chemistry changes (Pilewski et al., 2019). Carbonate mineral dissolution can have either a desirable effect for gas extraction by increasing pore size (Paukert Vankeuren et al., 2017) or cause instability and collapse in microfractures depending on the particular physical dynamics of the well (U.S. EIA, 2013). The extent of carbonate dissolution during shale-HFF reactions is typically controlled by the amount of carbonates in the shale as $\mathrm{HCl}$ is nearly ubiquitous in HFF (FracFocus) and is the only other substantial factor. The carbonate mineral content of the shale formation therefore primarily determines the system's $\mathrm{pH}$, and controls the 
various $\mathrm{pH}$ dependent reactions taking place in the shale reservoir. While numerous studies have investigated the dynamics of how carbonates may affect the shale-HFF system, none have analyzed these reactions under representative high pressure temperature well conditions and keeping all other variables constant (Wang et al., 2015, 2016). A recent study indicates that several other factors such as cation exchange on clay surfaces, adsorption of ions in organic matter, and formation of organo-metallic complex compounds affect mineral dissolution and precipitation reactions between shale and HFF (Pilewski et al., 2019). Therefore, to evaluate the true impact of carbonate content in shale-HFF reactions we need to keep other variable constant. The aim of this study was to isolate the effects of carbonate mineral content on the shale-HFF reactions keeping all the other variables constant, and mimicking the subsurface pressure temperature conditions using high pressure temperature reactors. Developing better understanding of how carbonates affect the geochemistry of hydraulic fracturing operations, operators can create more effective fracturing fluids targeting the local geology they are drilling into.

\subsection{Materials and Methods}

A series of experiments were conducted to identify the isolated effects of calcium carbonate abundance on shale- HFF interactions. All shale samples used in this study were LM-2 Marcellus Shale core, which is characterized in Pilewski et al., 2019 as shown in Table 1. LM-2 is a relatively immature sample of the Marcellus Shale $(\% \mathrm{Ro}=0.8)$ with high total organic carbon (15.4 wt $\%$ ), high carbonate content (21 wt \% calcite, $5 \mathrm{wt} \%$ dolomite), moderate mixed clay content (42 wt\%), and moderate pyrite content (5 wt\%) (Pilewski et al., 2019). The mineral composition of the shale was determined in Pilewski et al., 2019, by XRD analysis using a PANalytical X'Pert Pro X-ray diffractometer with a CuKa source. A high carbonate content 
sample was chosen to emphasize the difference between the unaltered and carbonate free samples. Sample exteriors were removed prior to grinding to prevent any contaminating drill mud using a cleaned Dremel tool. Shale samples were ground to 100 mesh to maximize surface area for reaction, with a small amount of shale cores was broken into $\sim 0.25 \mathrm{~cm}^{2}$ chips for SEMEDS analysis. The ground shale and shale chips were divided into two samples, SH-HFF which was not altered and SH-HFF $\left(-\mathrm{CO}_{3}\right)$ which had carbonate minerals removed. Carbonate removal in SH-HFF $\left(-\mathrm{CO}_{3}\right)$ was accomplished by digestion in trace metal grade $6 \mathrm{M} \mathrm{HCl}$ for 24 hours. Following acid digestion, the sample maintained a stable acidic $\mathrm{pH}$, indicating that all carbonate minerals had been dissolved. Hydraulic fracturing fluid was also reacted on its own to control for the changes it underwent independently due to heat and pressure and was named HFF. All pH measurements were taken with a calibrated YSI Pro Series Instrument equipped with a YSI Pro Series $1001 \mathrm{pH}$ sensor. A separate portion of the rock chips were also acid digested in order to collect pre-reaction SEM-EDS without changing the remaining mass of the main acid digested sample for the reactor experiment. After acid digestion, $\mathrm{SH}-\mathrm{HFF}\left(-\mathrm{CO}_{3}\right)$ was vacuum filtered to remove excess $\mathrm{HCl}$.

The mixture of synthetic brine and HFF was prepared using the methods reported in Paukert Vankeuren et al., 2017 (Table 2). Some proprietary chemicals that were used as part of the mixture in previous studies were no longer available. These included a gelling agent WGA15L, a clay stabilizer WCS-631LC, a friction reducer WFR-61LA, and a corrosion inhibitor WAI-251LC. Substitutes for these were based upon MSDS sheet data and common chemicals used in the same region for the same purposes per FracFocus. Petroleum distillates were used in place of the proprietary gelling agent and friction reducer, choline chloride replaced the proprietary clay stabilizer, and cinnamaldehyde replaced the proprietary corrosion inhibitor. 
The shale samples were mixed with HFF and heated and pressurized to in-situ proxy conditions. HFF was also reacted at proxy in-situ conditions without any shale present to control for reactions that occur in the fluid purely due to temperature and pressure changes. Two Parr $4768600 \mathrm{~mL}$ static autoclaves were used to carry out reactions at $100^{\circ} \mathrm{C}$ and $\sim 2,500$ psi for 14 days each in order to simulate shut-in phase conditions (Marcon et al., 2016; Vankeuren et al., 2017). Inert $\mathrm{N}_{2}$ (100\% pure) was used to pressurize the reactors. A borosilicate glass sleeve containing $420 \mathrm{~mL}$ of $\mathrm{HFF}$ and 20 grams of 100 mesh shale powder and 1 gram of shale chips at a fixed mass ratio of 20:1 were placed inside the reactors, with the shale and HFF mixed immediately before the pressurization and heating of the reactors following the methods of Macron et al., 2017. Shale chips had $\sim 1-1 / 2 \mathrm{~cm}^{2}$ area and were $\sim 1 \mathrm{~mm}$ thick. The shale free control reaction used $420 \mathrm{~mL}$ of synthetic HFF mixture.

Upon completion of the reactions at 14 days, samples were collected for analysis by ion chromatography (IC), dissolved inorganic carbon (DIC), gas chromatography - mass spectrometry (GC-MS), and inductively coupled plasma mass spectrometry (ICP-MS). Sampling for each method from the reactor vessel was done with a polyethylene Luer-Lock Syringe. IC samples were filtered to 0.22 microns using a syringe filter and collected in $10 \mathrm{~mL}$ plastic vials provided by the National Energy Technology Laboratory (NETL) with zero headspace. DIC samples were also collected in $10 \mathrm{~mL}$ plastic vials provided by NETL with zero headspace. GCMS samples were collected with zero headspace in $60 \mathrm{~mL}$ amber volatile organics analysis (VOA) vials acidified with HCL. Samples for ICP-MS were collected with zero headspace in the same $10 \mathrm{~mL}$ plastic vials provided by NETL after being filtered to $0.45 \mu \mathrm{m}$ and acidified with nitric acid. The reacted shale was vacuum filtered, and oven dried at $50^{\circ} \mathrm{C}$. All collected samples were immediately refrigerated after collection. 
Ion chromatography analysis was conducted at the NETL Pittsburgh campus on a ThermoFisher ICS-5000+ with AS11-HC column for anion and CS16 column for cation quantification. This method provided sulfate data with error no greater than $4 \%$ in each of the four standards run with the samples. The lower and upper limits of detection for sulfate were 0.2 - $25 \mathrm{mg} / \mathrm{L}$. At the 1:10 dilution factor, all of the samples were within the calibrated range. Citrate data gathered with this method had $4 \%$ and $3 \%$ error in the two standards run. The lower and upper calibration limits for citrate were $0.1-0.5 \mathrm{mg} / \mathrm{L}$.

ICP-MS was also conducted at the NETL Pittsburgh campus on their Perkin Elmer Nexion 300D instrument. Samples were run at 1:100 dilution. All species in all samples had a relative percent difference of less than $4 \%$ from duplicates.

Geochemical modeling of mineral solubility was performed using the Visual MINTEQ 3.1 modeling program. Temperature and $\mathrm{pH}$ values were input based on measured results. The SIT method of correction was used for ionic strength which was set at 0.5 to avoid overloading the program with a higher value. The model was run for kaolinite to determine the mole percent dissolved under the $\mathrm{pH}$ conditions of each shale reaction. Other components of the reaction were not included for this model.

DIC analysis was also conducted at NETL Pittsburgh campus. A Shimadzu Total Organic Carbon/Total Inorganic Carbon (TOC/TIC) analyzer was used. DI water was run first to flush the system of any residual contamination and the system was calibrated at $100 \mathrm{ppm}$. Two $100 \mathrm{ppm}$ and two $50 \mathrm{ppm}$ check standards were run. The greatest error was $14.0 \%$ and the average error was $11.76 \%$.

GC-MS analysis was conducted by Pace Analytical Services following EPA method SW8260B. Samples were put on ice immediately after collection and were brought to Pace 
Analytical Services' Morgantown Branch immediately following sampling and analyzed within 24 hours of sampling. In accordance with method SW8260B, samples were purged from the aqueous sample with helium gas flowing at $40 \mathrm{~mL} / \mathrm{min}$ for 11 minutes onto a Supelco Trap A, Tenax $24 \mathrm{~cm}$ sorbent trap. Volatile organics were liberated from the trap by heating it to $180^{\circ} \mathrm{C}$ and flushed into the GC-MS.

Qualitative analysis of spatial elemental distribution performed on the shale samples was done using the Oxford INCA EDS capabilities of the JEOL JSM-7600F SEM at the West Virginia University's Shared Research Facility. The chip portion of the dried reacted shales was separated and mounted on aluminum pin mounts with carbon tape. Each mounted chip was sputter coated with a gold-palladium source to prevent charging during SEM analysis.

\subsection{Results}

$p H$

The acidification process used for SH-HFF $\left(-\mathrm{CO}_{3}\right)$ had a pronounced effect on the final $\mathrm{pH}$ as shown in Figure 2. SH-HFF rose in $\mathrm{pH}$ from 2.2 to 6.2 after the reaction. This was not seen in SH-HFF (- $\left.\mathrm{CO}_{3}\right)$, where the carbonates had already been removed, and a slight decline from $\mathrm{pH} 2.2$ to 1.8 was observed.

\section{Ions in Solution}

Post reaction aluminum, iron, arsenic, cadmium, and uranium concentrations were all higher in SH-HFF $\left(-\mathrm{CO}_{3}\right)$ than in either SH-HFF or HFF (Table 3). Iron in solution was over 800 times higher in SH-HFF (- $\left.\mathrm{CO}_{3}\right)$ than in SH-HFF. Cadmium and arsenic were both many times more concentrated in SH-HFF (-CO $\left.\mathrm{CO}_{3}\right)$ than in SH-HFF as shown in Figure 3. Arsenic was 10.5 times more concentrated in SH-HFF $\left(-\mathrm{CO}_{3}\right)$ than in SH-HFF while HFF arsenic concentration 
was below quantification. Cadmium showed a similar trend with concentration in SH-HFF ($\mathrm{CO}_{3}$ ) 8.7 times greater than SH-HFF. Iron was also detected in the HFF sample at $36.42 \mathrm{mg} / \mathrm{L}$ though no shale was added, nor was any iron included in the HFF. This likely indicates some corrosion of the stainless-steel temperature probe in the reactor by the acidic conditions. Given the similar $\mathrm{pH}$ between $\mathrm{HFF}$ and $\mathrm{SH}-\mathrm{HFF}\left(-\mathrm{CO}_{3}\right)$ and the much greater iron concentration in SHHFF $\left(-\mathrm{CO}_{3}\right)$, this qualitatively does not affect our results. We also observed aluminum concentrations in SH-HFF $\left(-\mathrm{CO}_{3}\right)$ that were two orders of magnitude higher than the other samples. Based on XRD results, the primary source of aluminum in our shale samples are aluminosilicate clays which comprised $42 \%$ of the mineral content (Pilewski et al., 2019).

Both SH-HFF and SH-HFF (- $\left.\mathrm{CO}_{3}\right)$ had similarly low barium concentrations at $3.20 \mathrm{mg} / \mathrm{L}$ and $3.36 \mathrm{mg} / \mathrm{L}$ respectively. HFF had comparatively more barium at $52.29 \mathrm{mg} / \mathrm{L}$, but was still well below the $306 \mathrm{mg} / \mathrm{L}$ initial concentration. Sulfate displayed an opposite trend with SH-HFF and $\mathrm{SH}-\mathrm{HFF}\left(-\mathrm{CO}_{3}\right)$ at $162.45 \mathrm{mg} / \mathrm{L}$ and $137.63 \mathrm{mg} / \mathrm{L}$ respectively, and much lower in $\mathrm{HFF}$ at $6.27 \mathrm{mg} / \mathrm{L}$.

Citrate ion concentration was 10 times higher in SH-HFF $\left(-\mathrm{CO}_{3}\right)$ than in SH-HFF or HFF though still lower than the amount originally added as citric acid (Table 2). The IC used to detect organic anions reports total citrate ion concentration, though notably citrate and citric acid only vary by protonation as a matter of $\mathrm{pH}$ (Al-Khaldi et al., 2007). In the unreacted fluid $33.6 \mathrm{mg} / \mathrm{L}$ of citrate ion were initially included, while $20.44 \mathrm{mg} / \mathrm{L}$ were detected in SH-HFF $\left(-\mathrm{CO}_{3}\right)$, and only 1.97 and $1.10 \mathrm{mg} / \mathrm{L}$ were detected in SH-HFF and HFF respectively.

Dissolved inorganic carbon was highest in SH-HFF, followed by $\mathrm{SH}-\mathrm{HFF}\left(-\mathrm{CO}_{3}\right)$ and then HFF with $12.59,5.749$, and $1.463 \mathrm{mg} / \mathrm{L}$ respectively. Inorganic carbon speciation is $\mathrm{pH}$ dependent and would be predominantly $\mathrm{CO}_{2}$ (aq) in $\mathrm{SH}-\mathrm{HFF}\left(-\mathrm{CO}_{3}\right)$ and $\mathrm{HFF}$ and a mixture of 
$\mathrm{CO}_{2}$ (aq) and $\mathrm{HCO}_{3}{ }^{-}$in $\mathrm{SH}-\mathrm{HFF}\left(-\mathrm{CO}_{3}\right.$ ) (Stefansson et al., 2014). SH-HFF was 2.19 times higher than SH-HFF $\left(-\mathrm{CO}_{3}\right)$ and 8.60 times higher than $\mathrm{HFF}$, while $\mathrm{SH}-\mathrm{HFF}\left(-\mathrm{CO}_{3}\right)$ was 3.92 times higher than HFF

\section{SEM-EDS of Pyrite After Reaction}

Shown in Figure 4 are characteristic morphologies of pyrite crystals for SH-HFF and $\mathrm{SH}-\mathrm{HFF}\left(-\mathrm{CO}_{3}\right)$. EDS spectra in both samples revealed areas predominantly composed of iron and sulfur, which we interpret as pyrite. In SH-HFF, pyrite areas were mostly found as clusters of small crystals as shown in Figure 4. $\mathrm{SH}-\mathrm{HFF}\left(-\mathrm{CO}_{3}\right)$ exclusively displayed pyrite areas in the form of larger single crystals with much lower volume-to-surface area ratios. The crystalline precipitate that was collected from the HFF reaction primarily gave EDS spectra, indicating barium and sulfur composition. This was interpreted as evidence of barite precipitation; however, barium was found to be diffuse in both shale reactions and insufficiently concentrated to give useful EDS results from the shale.

\section{BTEX}

SH-HFF had significantly higher concentrations of benzene, toluene, ethylbenzene, and xylene (Figure 5). It was the only reaction in which ethylbenzene or toluene was detected and had $288 \%$ higher benzene, $960 \%$ higher m,p-xylene, and $792 \%$ higher o-xylene than SH-HFF ($\mathrm{CO}_{3}$ ). Only m,p-xylene was above detection in HFF and there was $1300 \%$ more in SH-HFF. All BTEX compounds detected in SH-HFF $\left(-\mathrm{CO}_{3}\right)$ and $\mathrm{HFF}$ are qualitative concentrations as they were found to be above the method detection limit but below the practical quantification limit for the GC-MS method used. Amounts detected in each reaction and limits of detection for each 
analyte are given in Table 4. Halogenated organics (1,2-Dichloroethane-d4, 4-

Bromofluorobenzene, Dibromofluoromethane, and Toluene-d8) were added to the samples

before analysis for use as surrogate recovery standards. These halogenated organics likely

interacted with the complex composition of the samples, as percent recoveries varied widely and in some cases exceeded standard limits.

\subsection{Discussion}

\section{Carbonate Dissolution}

The observed changes in $\mathrm{pH}$ following reaction indicate that carbonate minerals were successfully dissolved from SH-HFF $\left(-\mathrm{CO}_{3}\right)$ by the acidification process used prior to reaction (Figure 2). SH-HFF saw a significant $\mathrm{pH}$ increase from pre to post reaction, while SH-HFF ($\mathrm{CO}_{3}$ ) and HFF maintained a constant $\mathrm{pH}$. The only difference between the SH-HFF and SH-HFF (-CO3) sample was the lack of carbonate in the later we can conclude that the carbonates is the primary factor influencing the of shale-HFF reactions. These results are in agreement with previous studies that reacted shale samples of varying mineral composition with HFF and reported that $\mathrm{pH}$ in the post-reaction solution is strongly correlated with the carbonate content of the shale (Harrison et al., 2017 and Pilewski et al., 2019). The control of carbonate minerals on the $\mathrm{pH}$ has also been demonstrated by comparing the relatively low carbonate Marcellus Shale to the much higher carbonate Eagle Ford Shale (Jew et al., 2017).The higher carbonate Eagle Ford Shale had a consistently higher $\mathrm{pH}$ than the Marcellus Shale following reaction with acidic solutions. Our results also strongly support that the $\mathrm{pH}$ of SH-HFF reaction increased due to dissolving carbonate minerals, while the SH-HFF $\left(-\mathrm{CO}_{3}\right)$ maintained the lower $\mathrm{pH}$ due to lack of carbonates. 
The study by Harrison et al., 2017 also found that calcium in solution increased with the $\mathrm{pH}$ providing additional evidence that calcium carbonate $\left(\mathrm{CaCO}_{3}\right)$ is responsible for the $\mathrm{pH}$ change. However, in our experiment the calcium in solution does not show any trend, and we hypothesize that the high amount of calcium added to the brine component of our fracturing fluid mixture as calcium chloride probably swamped out any calcium trend related to $\mathrm{CaCO}_{3}$ dissolution (Table 2)

\section{Dissolution of Clay Minerals}

In the $\mathrm{SH}-\mathrm{HFF}\left(-\mathrm{CO}_{3}\right)$ reaction, aluminum in solution was at $29,835 \mu \mathrm{g} / \mathrm{L}$, but it was below the limit of detection $(25.1 \mu \mathrm{g} / \mathrm{L})$ in SH-HFF (Figure 6). The only source of aluminum in these reactions is the aluminosilicate mixed clay minerals present in the shale, indicating that clay dissolution occurred in the $\mathrm{SH}-\mathrm{HFF}\left(-\mathrm{CO}_{3}\right)$ reaction. Several clays have been shown to be most soluble at very low pH values and least soluble near pH 6 (Oelkers et al., 1994; Takahashi et al., 1995). The Visual MINTEQ 3.1 program shows that kaolinite was slightly soluble at $100^{\circ} \mathrm{C}$ and $\mathrm{pH} 1.89$ as in $\mathrm{SH}-\mathrm{HFF}\left(-\mathrm{CO}_{3}\right)$ and was not soluble when the $\mathrm{pH}$ was raised to 6.2 as it was in SH-HFF. In this simplified model, kaolinite was added as a finite solid and over 1800 times more dissolved at $\mathrm{pH} 1.89$ than 6.2 when the model reached equilibrium. Based on this simple modeling it seems likely that the absence of carbonates to buffer the $\mathrm{pH}$ can result in some clay mineral dissolution, which could potentially cause instability and collapse of microfractures.

Pyrite Dissolution

Like clay minerals, pyrite dissolution was also influenced by increased $\mathrm{pH}$ from carbonate dissolution. Organic rich shale sediments were originally deposited in an anoxic 
environment that was maintained upon the burial of the sediments. The resulting anoxic conditions in shale formations prior to drilling result in iron generally existing in the reduced form $\left(\mathrm{Fe}^{2+}\right)$. Iron sources in reservoir shales include pyrite, iron carbonate siderite, iron ions sorbed onto clays, and magnetite. However, at least $90 \%$ of the iron in shales is found in pyrite, which typically occurs as framboids (Jew et al., 2017). The system's Eh becomes much more oxidizing upon the introduction of oxidizing breakers and initially oxic water in HFF to the formation. Pyrite is composed of reduced iron and sulfur and becomes unstable under oxidized conditions leading to oxidation and dissolution. Pyrite's oxidation removes iron and sulfur from the mineral and is the primary mechanism of its dissolution. In this system, numerous reactions likely occur as the result of diverse oxidizing species in solution. Oxidizing breakers including ammonium persulfate can produce a range of oxidizing species such as the sulfate and hydroxide anions. These join dissolved oxygen in the initial HFF to begin oxidizing pyrite and other parts of the shale formation. The products of this, such as Fe III released from pyrite can then cyclically oxidize pyrite further (Bonnissel-Gissinger et al., 1998). A study by Wang et al., 2016 on pyrite oxidation in the Bakken Shale found increased $\mathrm{SO}_{4}{ }^{2-}$ concentrations as evidence of increased pyrite dissolution after reaction.

By controlling the $\mathrm{pH}$ of the chemical system, carbonates also influence the composition of organic compounds in solution which can act as ligands to chelate iron and oxidize it. Pyrite dissolution can be greatly accelerated by iron chelation with organic compounds by 2 to 3 orders of magnitude depending on conditions (Jones et al., 2015). This has been demonstrated both for citric acid, which is added to HFF to control iron, and bitumen mobilized from the shale formation (Jones et al., 2015; Jew et al., 2017). Both can be affected by carbonates via pH changes. Citric acid's level of protonation varies with $\mathrm{pH}$ which affects its reactivity. When 
carbonates raise the solution $\mathrm{pH}$, the citric acid molecule loses hydrogen and becomes a more reactive anion. Bitumen has an indeterminate chemical composition as it is a blend of soluble organic components found in shales. However, the organic acids present in bitumen are affected by $\mathrm{pH}$ in the same way that citric acid is.

Heavy metals such as arsenic and cadmium are commonly associated with pyrite in organic rich shales (Armstrong et al., 2019), and are released when pyrite is dissolved. This can pose an environmental hazard and indicate that pyrite dissolution has taken place in shale-HFF reactions. The collective results for iron, arsenic, and cadmium in solution are indicative that $\mathrm{SH}-$ HFF (- $\left.\mathrm{CO}_{3}\right)$ had substantially more pyrite dissolution than SH-HFF. Iron is a primary component of pyrite and heavy metals such as arsenic and cadmium are often associated with pyrite as impurities (Wang et al., 2016; Armstrong et al., 2019) and each was most concentrated in SHHFF (-CO $\mathrm{CO}_{3}$ ). As the LM-2 shale sample was comprised of 5\% pyrite by weight (Pilewski et al., 2019), pyrite is the presumptive primary source of each of these metals in the shale. The evidence from fluid chemistry for greater pyrite dissolution in SH-HFF $\left(-\mathrm{CO}_{3}\right)$ than in SH-HFF is corroborated by different morphologies of pyrite crystals on the surface of shale chips following reaction (Figure 4). Under the SEM in the SH-HFF chips, most pyrite crystals were found as framboids of many small crystals with large surface area to volume ratios, while in the SH-HFF $\left(-\mathrm{CO}_{3}\right)$ chips, the pyrite was found exclusively as larger single crystals. This possibly suggests that higher pyrite dissolution in the $\mathrm{SH}-\mathrm{HFF}\left(-\mathrm{CO}_{3}\right)$ dissolved the smaller framboidal crystals (seen in SH-HFF) due to their greater surface area to volume ratio, leaving only the most robust pyrite crystals intact. In a sample that had experienced significant pyrite dissolution, we would expect to find only stout pyrite crystals with relatively smaller surface areas for dissolution to take place on as we observed in SH-HFF $\left(-\mathrm{CO}_{3}\right)$. SEM analysis didn't show 
evidence of Iron oxyhydroxide precipitation in either shale reaction. However, it is possible that greater iron oxyhydroxide precipitation in SH-HFF due to the higher $\mathrm{pH}$ may have drawn down iron and heavy metals in solution.

The citrate ion content was an order of magnitude greater in SH-HFF $\left(-\mathrm{CO}_{3}\right)$ than in SHHFF (Figure 7). The higher citrate in SH-HFF (- $\left.\mathrm{CO}_{3}\right)$ could plausibly be responsible for the higher pyrite dissolution through iron chelation and oxidation (Jones et al., 2015). During this process, citric acid binds to iron ions as an organic ligand, which increases the rate of iron II to iron III oxidation by 2 to 3 orders of magnitude (Jones et al., 2015). Organic chelation of iron has been shown to increase the rate of pyrite oxidation and lead to greater arsenic and iron release from shale (Wang et al., 2016). Our data also demonstrates this trend as shown in Figure 7. Under acidic conditions, pyrite dissolution increases as a result of increased iron oxidation. Oxidized iron III released from pyrite dissolution can oxidize sulfur in pyrite to sulfate resulting in a cyclical breakdown of pyrite catalyzed by citric acid (Bonnissel-Gissinger et al., 1998).

\section{Carbonate Effect on Fracturing Fluid chemistry}

The citrate ion in solution detected by the IC was likely the citric acid that was added to the HFF and had been retained at $61 \%$ of the initial concentration in SH-HFF $\left(-\mathrm{CO}_{3}\right)$ and 10 times less in SH-HFF and HFF. The disparity in citric acid left in solution may be the result of calcium citrate precipitation, which occurs when the solution's $\mathrm{pH}$ is greater than 6 , as was the case in SH-HFF, which had a final pH of 6.2 (Al-Khaldi et al., 2007). SH-HFF also had carbonate minerals that might have buffered and raised the $\mathrm{pH}$ of the reaction. On the other hand, the SH-HFF $\left(-\mathrm{CO}_{3}\right)$ sample lacked these carbonates and had a $\mathrm{pH}$ of 1.8 , which did not allow for calcium citrate precipitation (Figure 8). Furthermore, when deprotonated citrate anions attach to 
positive sites on the calcite surface and the SH-HFF provided these sites for calcium citrate precipitation, decreasing the citrate concentrations in solution. Conversely, SH-HFF $\left(-\mathrm{CO}_{3}\right)$ had a pH below citric acid's pKa1 of 2.79 (Al-Khaldi et al., 2007) and citric acid was less likely to react with other chemical species while protonated. Though HFF had a similar $\mathrm{pH}$ and lacked any carbonate minerals, the detected citrate was similar to SH-HFF rather than SH-HFF $\left(-\mathrm{CO}_{3}\right)$. It is likely that this is a result of the ammonium persulfate not reacting with any minerals and instead of reacting with the organic components, including citric acid of the fracturing fluid. AlKhaldi et al., 2007 found that oxidizing breakers in fracturing fluid predominantly reacted with pyrite when oxidizer concentrations were low, and more aggressively oxidized shale organic matter when the amount of oxidizer needed to dissolve pyrite was exceeded. It is likely the case that ammonium persulfate preferentially reacted with other species in the shale reactions, but those species were not present in HFF.

Carbonate minerals in the shale-HFF reaction may have also affected oxidation by reducing the efficiency of the ammonium persulfate in the fracturing fluid as an oxidizing species. Ammonium persulfate is a highly soluble salt $\left(\mathrm{NH}_{4}\right)_{2} \mathrm{~S}_{2} \mathrm{O}_{8}$ and dissociates into separate ions in solution. The persulfate ion $\left(\mathrm{S}_{2} \mathrm{O}_{8}^{-2}\right)$ is strongly oxidizing and reduces to two sulfate ions which are also strongly oxidizing. This step requires activation energy and can be limiting in ambient conditions (Liang et al., 2008). However, at $100^{\circ} \mathrm{C}$ for 14 days, the persulfate should have had excess time to break down and react as it has been shown to fully decompose in 2 hours at $90^{\circ} \mathrm{C}$ and to decompose more quickly at higher temperatures (Babu et al., 2002). The sulfate ions react with water to produce $\mathrm{HSO}_{4}^{-}$and $\mathrm{OH}^{-}$, the latter of which is a reactive oxidizing species (ROS) (Deng and Ezyske, 2011). Carbonate dissolution produces bicarbonate ions $\left(\mathrm{HCO}_{3}{ }^{-}\right)$, which are ROS scavengers and react with oxidizing hydroxide ions to produce water 
and carbonate ions which are not oxidizing. Because of this, alkalinity from carbonate minerals reduces ammonium persulfate's overall ability to oxidize (Deng and Ezyske, 2011).

\section{BTEX Oxidation}

BTEX compounds were all much higher in SH-HFF than in $\mathrm{SH}-\mathrm{HFF}\left(-\mathrm{CO}_{3}\right)$ or HFF

(Figure 5). A major causal factor for the discrepancy between the shale reactions may be the aforementioned oxidizing strengths of the solutions. In environmental remediation, ammonium persulfate is used as a remediation strategy (Deng and Ezyske, 2011; Hilles et al., 2016) to oxidize BTEX compounds and it should be doing so in our reactions as well. The greater efficacy of ammonium persulfate as an oxidizer in $\mathrm{SH}-\mathrm{HFF}\left(-\mathrm{CO}_{3}\right)$ due to the absence of ROS scavenging bicarbonate may lead to greater oxidation of BTEX compounds in solution.

Higher oxidation of BTEX compounds is mirrored by evidence of increased shale organic matter oxidation in SH-HFF $\left(-\mathrm{CO}_{3}\right)$. Uranium in shale (Figure 3) is associated with organic matter and is released into under oxidizing conditions when organic matter is broken down (Armstrong et al., 2019). Higher oxidation is also supported by the comparative increase in dissolved inorganic carbon in SH-HFF $\left(-\mathrm{CO}_{3}\right)$ to HFF from 1.463 to $5.749 \mathrm{mg} / \mathrm{L}$ (Figure 9). The oxidative decomposition of BTEX has been shown to produce carbon dioxide (Lovley, 1997). As the acid treatment applied to $\mathrm{SH}-\mathrm{HFF}\left(-\mathrm{CO}_{3}\right)$ removed all of the carbonate minerals before reaction, and the low $\mathrm{pH}$ of the fluid indicated that no carbonate dissolution had taken place to buffer it, the probable source of dissolved inorganic carbon is the carbon dioxide produced from oxidized organics. HFF had a similar $\mathrm{pH}$ of 2.3 to $\mathrm{SH}-\mathrm{HFF}\left(-\mathrm{CO}_{3}\right)$ at 1.8 and experienced the same pressure and temperature regimen's effects on $\mathrm{CO}_{2}$ solubility but lacked shale organic matter to oxidize and therefore had much lower dissolved inorganic carbon in solution. The 
uranium and dissolved inorganic carbon in solution both indicate that $\mathrm{SH}-\mathrm{HFF}\left(-\mathrm{CO}_{3}\right)$

experienced organic matter oxidation, which would also explain the low BTEX in solution.

\section{Barium and Sulfate}

Barite appears to have precipitated in all three reactions as barium is much lower in all three post-reaction solutions compared to the initial concentration that was added to the fracturing fluid (Figure 10). Sulfate levels were generally higher but displayed an opposite trend. Barite is typically oversaturated under well conditions and will precipitate (Paukert Vankeuren et al., 2017). In HFF, sulfate was the limiting factor as its only source was the breakdown of persulfates, and there was more barium added to the fracturing fluid stoichiometrically. In the shale reactions, sulfate was released from pyrite dissolution, but there was relatively little barium released, so it was likely the limiting reagent. In SEM-EDS analysis, shale chips from both reactions indicated extremely diffuse barium with no clusters or identifiable crystals. It is noteworthy that despite showing other evidence of higher pyrite oxidation, $\mathrm{SH}-\mathrm{HFF}\left(-\mathrm{CO}_{3}\right)$ actually had lower sulfate than SH-HFF, though it is a product of pyrite oxidation. It is likely that the oxidation reactions with organics discussed in the section above led to the binding of the sulfur species with shale organic matter. Evidence of sulfur uptake by organic matter in shaleHFF reactions has been found previously, particularly during kerogen oxidation (Yan et al., 2013; Hull et al., 2019). It is also possible that some of the sulfur reacted with BTEX compounds or the oxidized products of BTEX compounds.

\subsection{Conclusions}

The results of our study clearly demonstrate when designing the chemical composition HFF, the carbonate mineral content in shales must be accounted for as it can have an 
overwhelming effect on several shale-HFF reactions. The balance of carbonate minerals in the shale formation and acid added in the HFF will determine the $\mathrm{pH}$ and alkalinity of downhole conditions. This can dramatically impact the efficacy of other valuable fracturing fluid ingredients such as citric acid, which can precipitate out of solution on calcite, and oxidizing breakers that can be limited by bicarbonate scavenging of their reactive species.

The balance of different reactive species in the HFF and the carbonate content of shale will control the carbonate, clay, and pyrite dissolution in addition to barite and iron oxide scaling that can ultimately affect the porosity and structural integrity of fractures in the well. The carbonate minerals and HFF interactions with shale organic matter can also affect the release of heavy metals and volatile organic contaminants into produced water released on the surface.

In this study, we found that in SH-HFF reaction in the presence of carbonates increased $\mathrm{pH}$ dramatically. The $\mathrm{pH}$ increase is accompanied by a lack of aluminum released in solution, indicating that carbonates prevented clay mineral dissolution. Lower citrate ion concentration in the SH-HFF reaction indicated that citric acid included in HFF was less effective due to the precipitation of calcium citrate. This is also hypothesized as a cause for the decrease in interpreted pyrite dissolution based on the decrease in iron and pyrite-associated heavy metals in solution, as well as differences in SEM-EDS images of pyrite between the two shale reactions. The oxidizing breaker ammonium persulfate was also believed to be rendered less effective in dissolving pyrite through oxidation. This decline in oxidizer efficacy is attributed to the ROS scavenging by carbonate and bicarbonate anions. Further evidence of lower oxidizing strength by ROS scavenging is indicated by lower uranium released into solution from oxidized organic matter, and greater BTEX compounds in solution. Higher DIC in SH-HFF $\left(-\mathrm{CO}_{3}\right)$ than HFF also 
indicated that the greater oxidizer effectiveness of SH-HFF $\left(-\mathrm{CO}_{3}\right)$ led to organic carbon oxidation.

Overall carbonate minerals in the in SH-HFF reactions decreased the clay mineral and pyrite dissolution, decreased heavy metals released into solution, and increased the amount of BTEX compounds in the post reaction solution. With the exception of the increased BTEX, these are all positive trends for drilling operations. By minimizing pyrite dissolution, operators also minimize sulfate and iron in solution to cause barite and iron hydroxide scaling, as well as contamination by pyrite associated heavy metals. Depending on the mineralogy and pressures in a well, preventing clay mineral dissolution may also prevent microfracture instability and improve permeability. In carbonate-poor shales, operators may find that reducing the hydrochloric acid used in fracturing fluid may help maintain a higher solution $\mathrm{pH}$. They may also find that using enzyme-based breakers instead of oxidizing ones to break-up gelling agents prevents unintended pyrite oxidation. These practices and a better understanding of how carbonate minerals affect shale-HFF interactions will enable shale-gas operators to improve long term yield and reduce environmental risks posed by the operation. 


\subsection{Conclusions}

As with most geochemical reactions, the two master variables controlling changes in the hydraulically fractured shale system's mineralogy are $\mathrm{pH}$ and Eh. During the shut-in phase of a hydraulic fracturing operation, the system's pH is primarily governed by the balance of acid in the HFF and the buffering carbonate minerals in the shale (Wang, et al. 2015; Marcon, et al. 2017). The Eh is largely controlled by the dissolved $\mathrm{O}_{2}$ in HFF and oxidizing components of the HFF such as ammonium persulfate interacting with the reduced conditions of the formation (Marcon et al. 2017). Changes in the $\mathrm{pH}$ and oxidizing strength of the solution control the dissolution of various mineral phases all and the concentration of several dissolved species, which control the precipitation of secondary minerals in concert with the Eh and $\mathrm{pH}$.

In this study, three reactions were conducted under representative conditions for the shutin phase of a hydraulically fractured well. One between a fracturing fluid/brine mixture and a Marcellus Shale sample. A second reaction identical to the first, except the shale sample had been acidified to remove carbonates and a third control reaction with only the fracturing fluid/brine mixture. These reactions illustrated carbonate minerals' ability to alter both the $\mathrm{pH}$ and Eh of the reaction with a range of resulting effects.

In this study, we found that the presence of carbonates increased $\mathrm{pH}$ dramatically. The $\mathrm{pH}$ increases in conjunction with no released aluminum indicated that carbonates prevented clay mineral dissolution. Decreased citrate ion concentration in the high $\mathrm{pH}$ carbonate reaction indicated that citric acid included in HFF was less effective due to the precipitation of calcium citrate. This is implicated as a cause for the decrease in interpreted pyrite dissolution which was based on the decrease in iron and pyrite-associated heavy metals in solution, as well as 
differences in SEM-EDS images of pyrite between the two shale reactions. The oxidizing breaker ammonium persulfate was also believed to be rendered less effective and less able to dissolve pyrite through oxidation. We believe this decrease in oxidizer efficacy is the result of ROS scavenging by carbonate and bicarbonate anions. We found further evidence for decreased oxidizing strength by ROS scavenging from lower uranium released into solution from oxidized organic matter, and greater BTEX compounds in solution which were not oxidized during the reaction. Greater DIC in SH-HFF $\left(-\mathrm{CO}_{3}\right)$ than $\mathrm{HFF}$ also indicated that the greater oxidizer effectiveness of SH-HFF $\left(-\mathrm{CO}_{3}\right)$ led to organic carbon oxidation.

Overall, carbonate minerals in the reactions decreased clay mineral and pyrite dissolution, decreased heavy metals released into solution, and increased the amount of BTEX compounds in solution after the reaction. With the exception of the increased BTEX, these are all positive trends for drilling operations. By minimizing pyrite dissolution, operators also minimize sulfate and iron in solution to cause barite and iron hydroxide scaling, as well as contamination by pyrite associated heavy metals. Depending on the mineralogy and pressures in a well, preventing clay mineral dissolution may also prevent microfracture instability and improve permeability. In carbonate-poor shales, operators may find that reducing the hydrochloric acid used in fracturing fluid may help maintain a higher solution $\mathrm{pH}$. They may also find that using enzyme-based breakers instead of oxidizing ones to break-up gelling agents prevents unintended pyrite oxidation. These practices and a better understanding of how carbonate minerals affect shale-HFF interactions will enable shale-gas operators to improve long term yield and reduce environmental risks posed by the operation. 


\subsection{References}

Abualfaraj, N., Gurian, P.L., and Olson, M.S., 2014, Characterization of Marcellus Shale Flowback Water: Environmental Engineering Science, v. 31, p. 514-524, doi:10.1089/ees.2014.0001.

Al-Khaldi, M.H., Nasr-El-Din, H.A., Mehta, S., and Al-Aamri, A.D., 2007, Reaction of citric acid with calcite: Chemical Engineering Science, v. 62, p. 5880-5896, doi:10.1016/j.ces.2007.06.021.

Armstrong, J.G.T., Parnell, J., Bullock, L.A., Boyce, A.J., Perez, M., and Feldmann, J., 2019, Mobilisation of arsenic, selenium and uranium from Carboniferous black shales in west Ireland: Applied Geochemistry, v. 109, p. 104401, doi:10.1016/j.apgeochem.2019.104401.

Arthur, J.D., and Layne, M., 2008, Hydraulic Fracturing Considerations for Natural Gas Wells of the Marcellus Shale: , p. 17.

Babu, M.N., Sahu, K.K., and Pandey, B.D., 2002, Zinc recovery from sphalerite concentrate by direct oxidative leaching with ammonium, sodium and potassium persulphates: Hydrometallurgy, v. 64, p. 119-129, doi:10.1016/S0304-386X(02)00030-0.

Bonnissel-Gissinger, P., Alnot, M., Ehrhardt, J.-J., and Behra, P., 1998, Surface Oxidation of Pyrite as a Function of pH: Environmental Science \& Technology, v. 32, p. 2839-2845, doi:10.1021/es980213c.

Deng, Y., and Ezyske, C.M., 2011, Sulfate radical-advanced oxidation process (SR-AOP) for simultaneous removal of refractory organic contaminants and ammonia in landfill leachate: Water Research, v. 45, p. 6189-6194, doi:10.1016/j.watres.2011.09.015.

FracFocus Chemical Disclosure Registry, http://fracfocus.org/, accessed 15 February 2019.

Harrison, A.L., Jew, A.D., Dustin, M.K., Thomas, D.L., Joe-Wong, C.M., Bargar, J.R., Johnson, N., Brown, G.E., and Maher, K., 2017, Element release and reaction-induced porosity alteration during shale-hydraulic fracturing fluid interactions: Applied Geochemistry, v. 82, p. 47-62, doi:10.1016/j.apgeochem.2017.05.001.

Hilles, A.H., Abu Amr, S.S., Hussein, R.A., El-Sebaie, O.D., and Arafa, A.I., 2016, Performance of combined sodium persulfate/ $\mathrm{H} 2 \mathrm{O} 2$ based advanced oxidation process in stabilized landfill leachate treatment: Journal of Environmental Management, v. 166, p. 493-498, doi:10.1016/j.jenvman.2015.10.051.

Hull, K.L., Jacobi, D., and Abousleiman, Y.N., 2019, Oxidative Kerogen Degradation: A Potential Approach to Hydraulic Fracturing in Unconventionals: Energy \& Fuels, v. 33, p. 4758-4766, doi:10.1021/acs.energyfuels.9b00104. 
Jew, A.D., Dustin, M.K., Harrison, A.L., Joe-Wong, C.M., Thomas, D.L., Maher, K., Brown, G.E., and Bargar, J.R., 2017, Impact of Organics and Carbonates on the Oxidation and Precipitation of Iron during Hydraulic Fracturing of Shale: Energy \& Fuels, v. 31, p. 3643-3658, doi:10.1021/acs.energyfuels.6b03220.

Jones, A.M., Griffin, P.J., and Waite, T.D., 2015, Ferrous iron oxidation by molecular oxygen under acidic conditions: The effect of citrate, EDTA and fulvic acid: Geochimica et Cosmochimica Acta, v. 160, p. 117-131, doi:10.1016/j.gca.2015.03.026.

Kondash, A., and Vengosh, A., 2015, Water Footprint of Hydraulic Fracturing: Environmental Science \& Technology Letters, v. 2, p. 276-280, doi:10.1021/acs.estlett.5b00211.

Liang, C., Huang, C.-F., and Chen, Y.-J., 2008, Potential for activated persulfate degradation of BTEX contamination: Water Research, v. 42, p. 4091-4100, doi:10.1016/j.watres.2008.06.022.

Lovley, D.R., 1997, Potential for anaerobic bioremediation of BTEX in petroleum-contaminated aquifers: Journal of Industrial Microbiology and Biotechnology, v. 18, p. 75-81, doi:10.1038/sj.jim.2900246.

Marcon, V., Joseph, C., Carter, K.E., Hedges, S.W., Lopano, C.L., Guthrie, G.D., and Hakala, J.A., 2017, Experimental insights into geochemical changes in hydraulically fractured Marcellus Shale: Applied Geochemistry, v. 76, p. 36-50, doi:10.1016/j.apgeochem.2016.11.005.

Morsy, S., Sheng, J.J., Hetherington, C.J., Soliman, M.Y., and Ezewu, R.O., 2013, Impact of Matrix Acidizing on Shale Formations, in SPE Nigeria Annual International Conference and Exhibition, Lagos, Nigeria, Society of Petroleum Engineers, doi:10.2118/167568MS.

Oelkers, E.H., Schott, J., and Devidal, J.-L., 1994, The effect of aluminum, pH, and chemical affinity on the rates of aluminosilicate dissolution reactions: Geochimica et Cosmochimica Acta, v. 58, p. 2011-2024, doi:10.1016/0016-7037(94)90281-X.

PA DEP, Hydraulic Fracturing Overview, http:// $\square$ les.dep.state.pa.us/OilGas/BOGM/BOGMPortalFiles/MarcellusShale/DEP\%20Fr acing\%20overview.pdf.

Paukert Vankeuren, A.N., Hakala, J.A., Jarvis, K., and Moore, J.E., 2017, Mineral Reactions in Shale Gas Reservoirs: Barite Scale Formation from Reusing Produced Water As Hydraulic Fracturing Fluid: Environmental Science \& Technology, v. 51, p. 9391-9402, doi:10.1021/acs.est.7b01979.

Pilewski, J., Sharma, S., Agrawal, V., Hakala, J.A., and Stuckman, M.Y., 2019, Effect of maturity and mineralogy on fluid-rock reactions in the Marcellus Shale: Environmental Science: Processes \& Impacts, v. 21, p. 845-855, doi:10.1039/C8EM00452H. 
Schulz, K.J., DeYoung, J.H., Jr., Seal, R.R., II, and Bradley, D.C., eds., 2017, Critical mineral resources of the United States-Economic and environmental geology and prospects for future supply: U.S. Geological Survey Professional Paper 1802, 797 p., http://doi.org/10.3133/pp1802.

Stefánsson, A., Bénézeth, P., and Schott, J., 2014, Potentiometric and spectrophotometric study of the stability of magnesium carbonate and bicarbonate ion pairs to $150^{\circ} \mathrm{C}$ and aqueous inorganic carbon speciation and magnesite solubility: Geochimica et Cosmochimica Acta, v. 138, p. 21-31, doi: 10.1016/j.gca.2014.04.008.

Takahashi, T., Fukuoka, T., and Dahlgren, R.A., 1995, Aluminum solubility and release rates from soil horizons dominated by aluminum-humes complexes: Soil Science and Plant Nutrition, v. 41, p. 119-131, doi:10.1080/00380768.1995.10419565.

U.S. EIA, Updates to the Marcellus Shale Play Maps, U.S. EIA, 2013, 14.

U.S. EIA, Updates to the Marcellus Shale Play Maps, U.S. EIA, 2017, 14.

U.S. EIA, Updates to the Marcellus Shale Play Maps, U.S. EIA, 2019, 14.

Wang, L., Burns, S., Giammar, D.E., and Fortner, J.D., 2016, Element mobilization from Bakken shales as a function of water chemistry: Chemosphere, v. 149, p. 286-293, doi:10.1016/j.chemosphere.2016.01.107.

Wang, L., Fortner, J.D., and Giammar, D.E., 2015, Impact of Water Chemistry on Element Mobilization from Eagle Ford Shale: Environmental Engineering Science, v. 32, p. 310 320, doi:10.1089/ees.2014.0342.

Yan, J., Jiang, X., Han, X., and Liu, J., 2013, A TG-FTIR investigation to the catalytic effect of mineral matrix in oil shale on the pyrolysis and combustion of kerogen: Fuel, v. 104, p. 307-317, doi:10.1016/j.fuel.2012.10.024. 


\subsection{Figures}

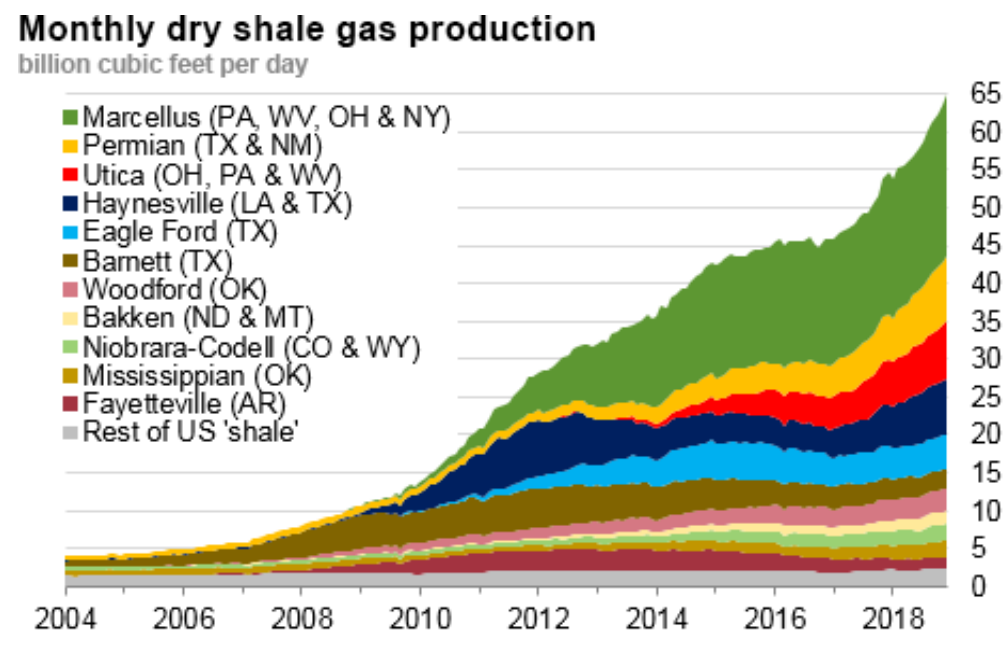

Figure 1: Dry shale gas production in the United States by formation (U.S. EIA, 2019)

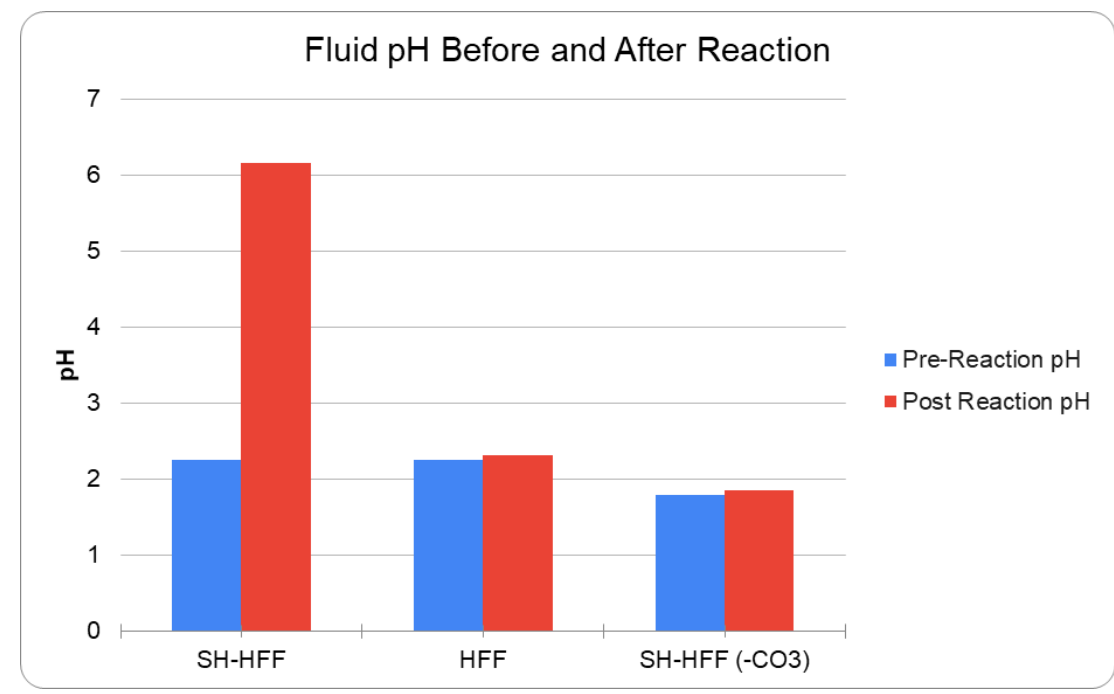

Figure 2 - Post-reaction $\mathrm{pH}$ for each sample versus $\mathrm{pH}$ measured immediately before reaction. 


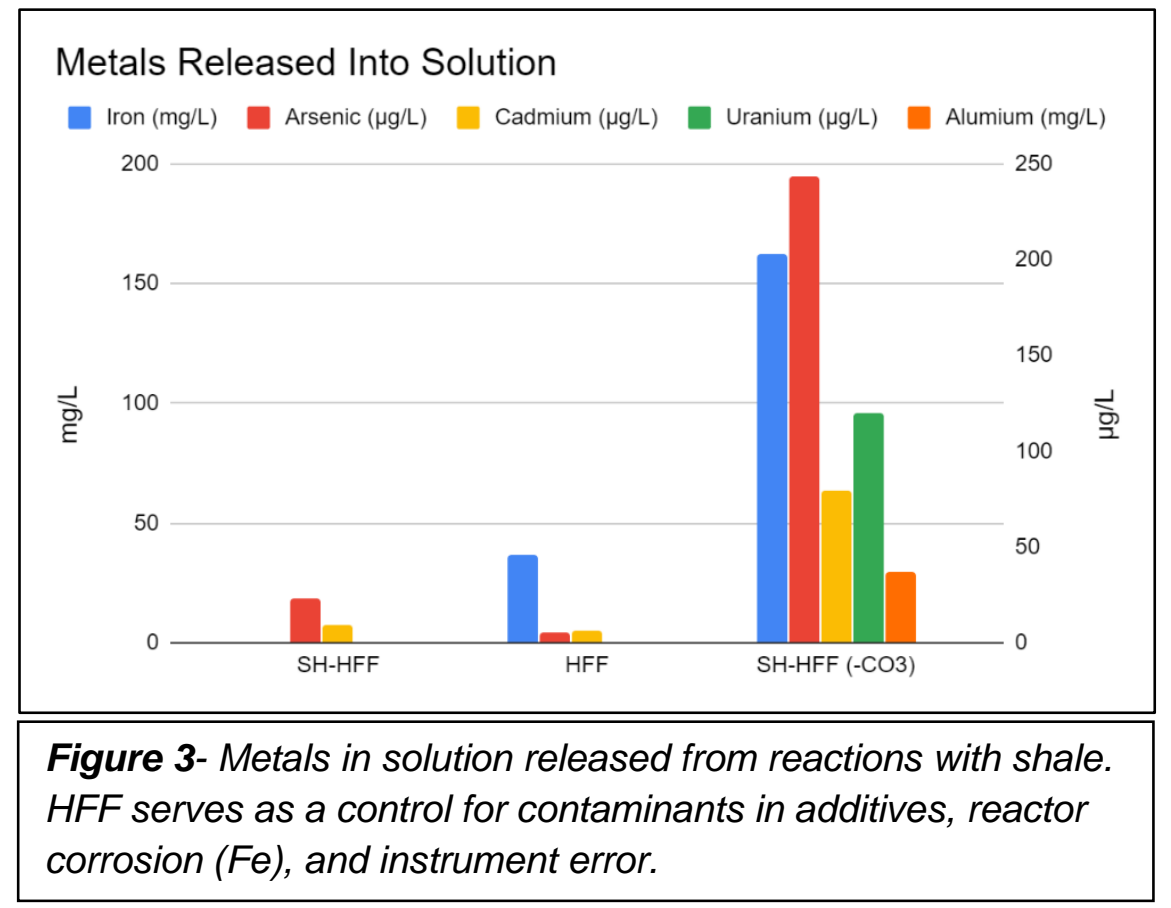

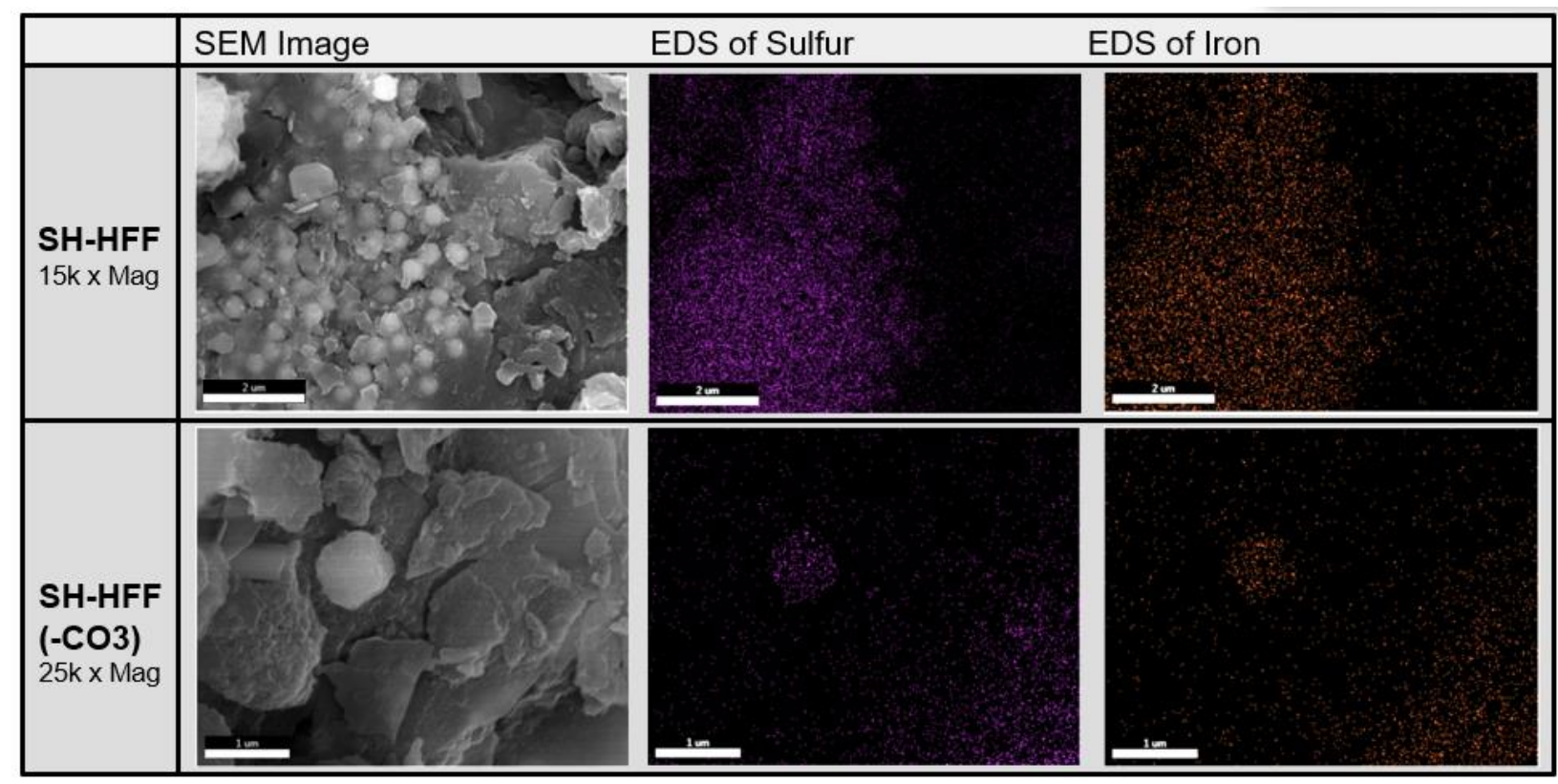

Figure 4- SEM and SEM-EDS images of reacted SH-HFF and SH-HFF (-CO3) shale chips. The sulfur and iron dense areas detected by EDS are presumed to be pyrite. 


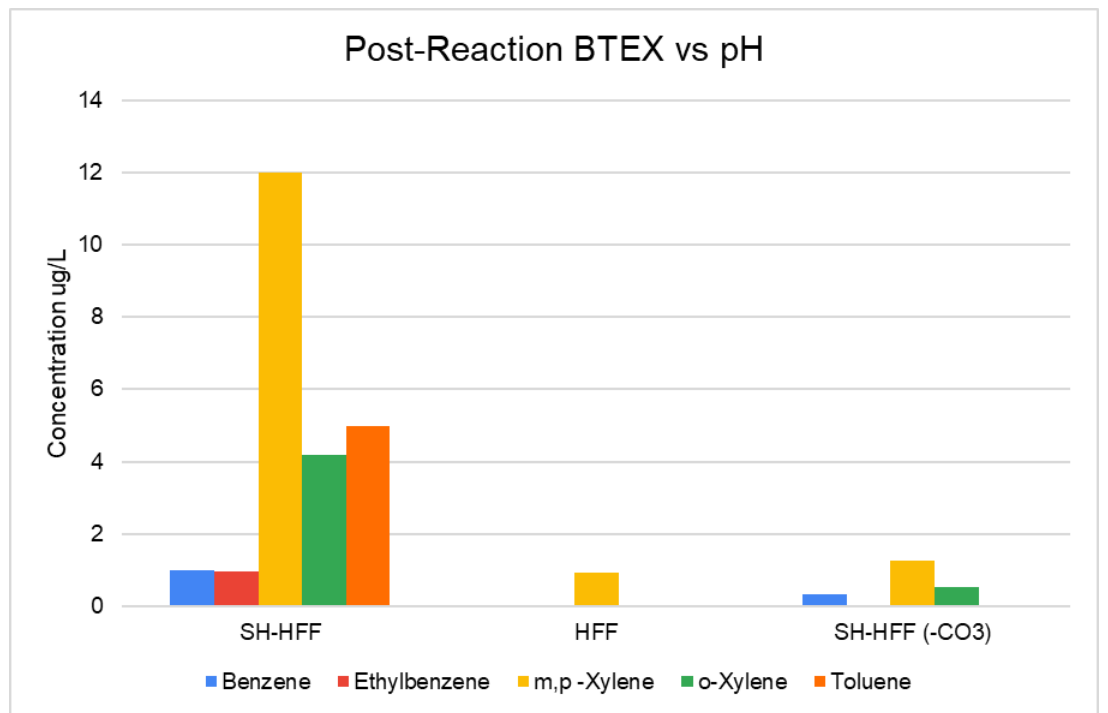

Figure 5- BTEX in solution for each reaction by GC-MS.

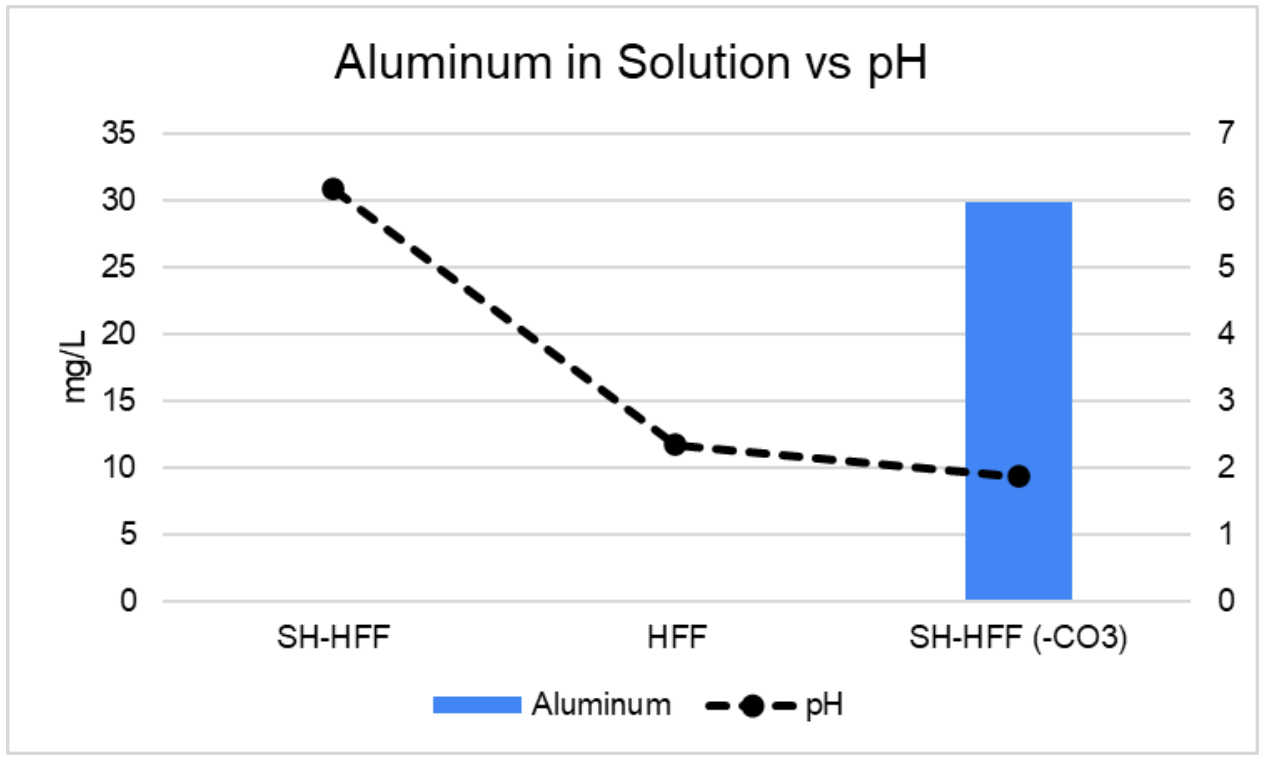

Figure 6- Aluminum in solution plotted against $\mathrm{pH}$ to highlight the role of $\mathrm{pH}$ in aluminum dissolution from clay minerals. 


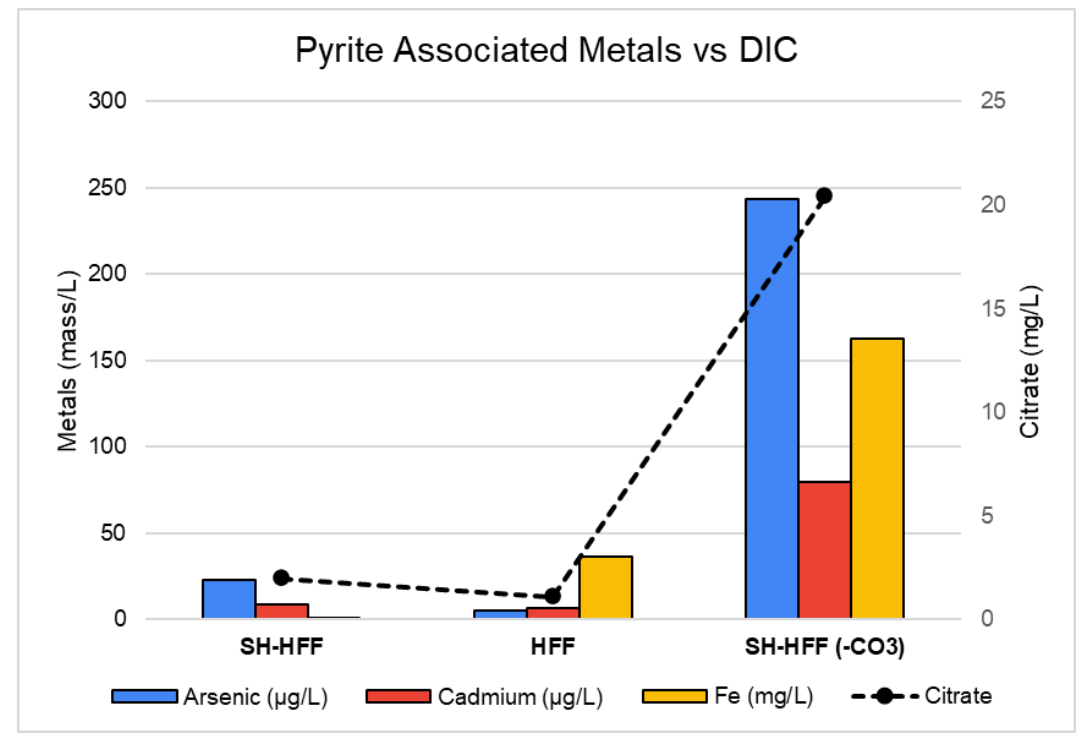

Figure 7- Metals associated with pyrite in solution plotted against total citrate in solution to highlight citric acid's roll in pyrite dissolution.

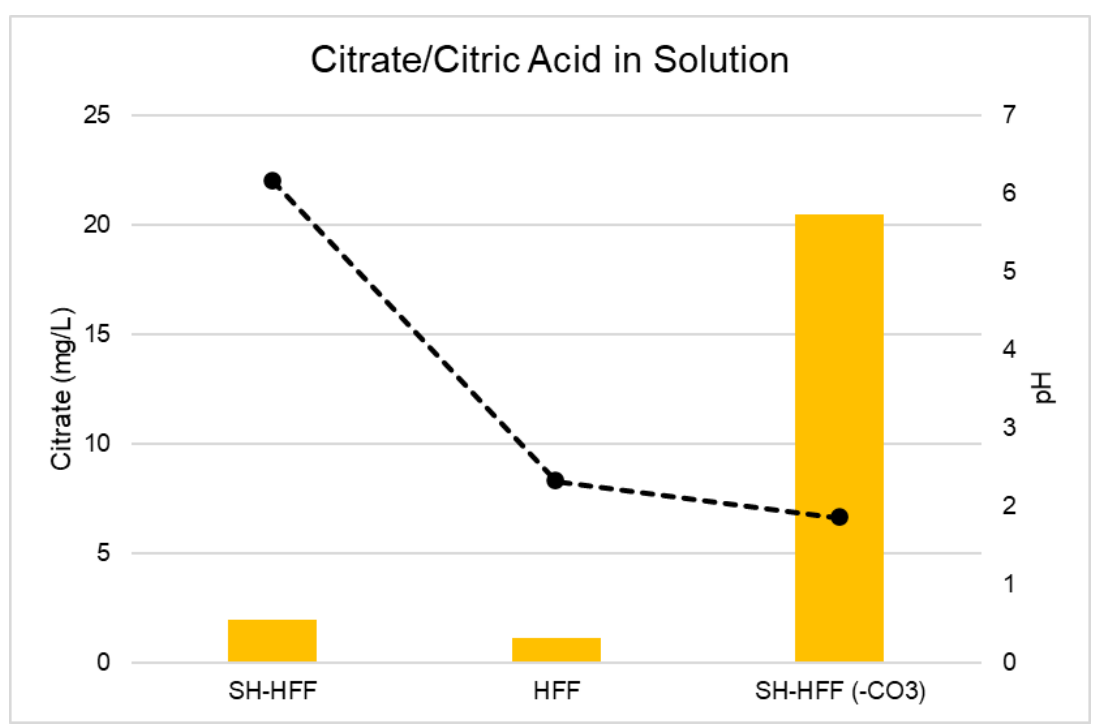

Figure 8-Citrate plotted against $\mathrm{pH}$ demonstrating the $\mathrm{pH}$ dependency of calcium citrate. 


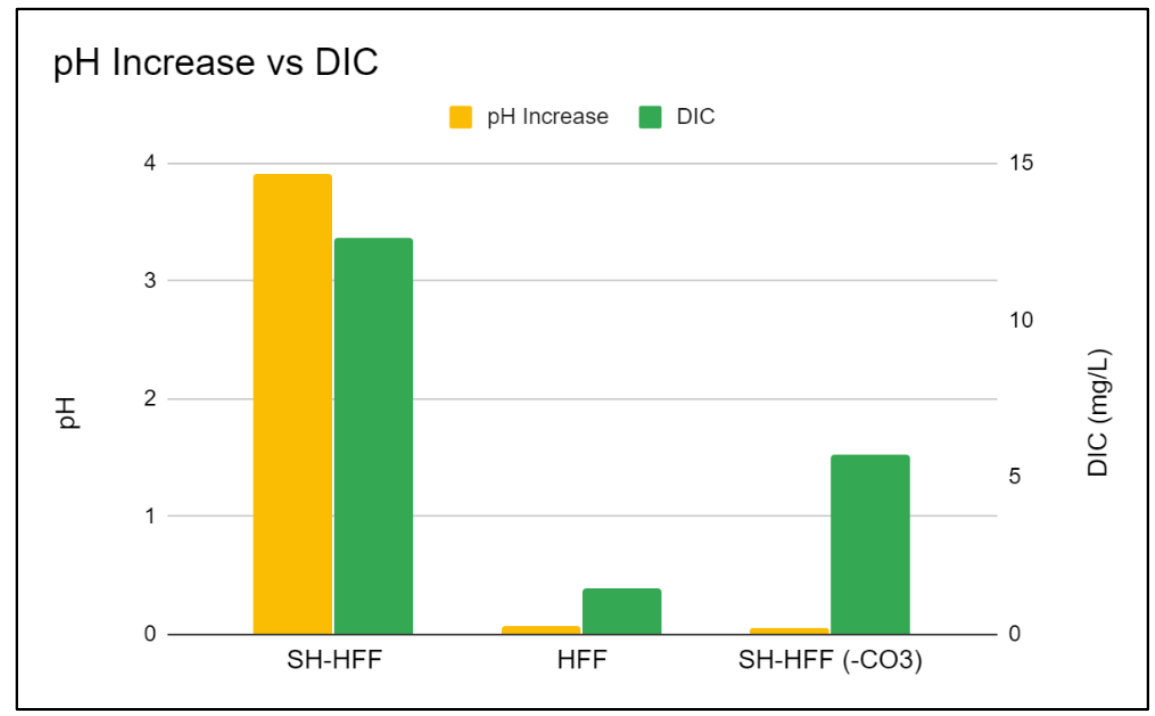

Figure 9- The change in $\mathrm{pH}$ due to carbonate dissolution plotted with DIC.

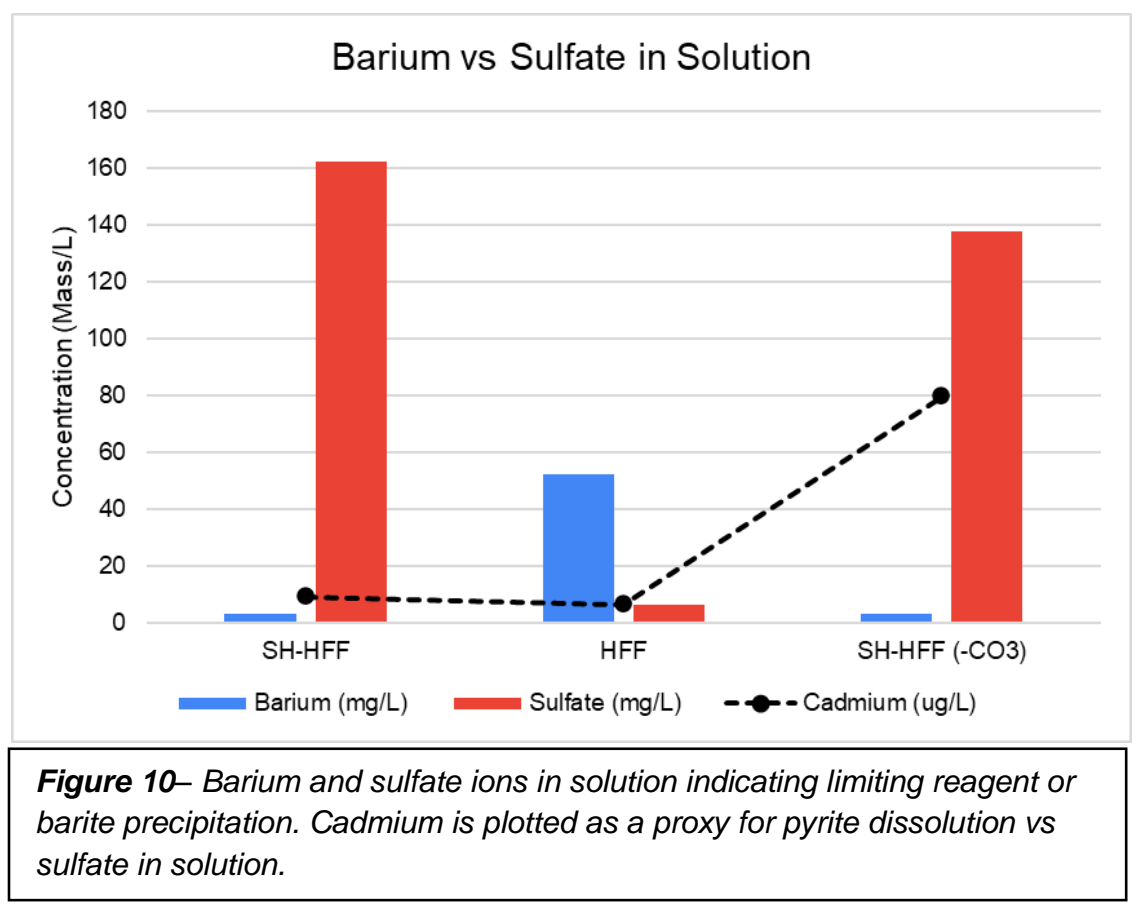




\subsection{Tables}

\begin{tabular}{|l|l|}
\hline Shale Sample & LM-2 \\
\hline Depth (ft) & 5825.7 \\
\hline \% Ro & 0.8 \\
\hline Tmax ( $\left.{ }^{\circ} \mathrm{C}\right)$ & 443 \\
\hline TOC (wt\%) & 15.4 \\
\hline Quartz (wt\%) & 28 \\
\hline Calcite (wt\%) & 21 \\
\hline Dolomite (wt\%) & 5 \\
\hline Pyrite (wt\%) & 5 \\
\hline Mixed Clays (wt\%) & 42 \\
\hline
\end{tabular}

Table 1- LM-2 shale mineral composition, depth and organic content description (Pilewski et al., 2019). 


\begin{tabular}{|c|c|c|}
\hline \multicolumn{3}{|c|}{$\begin{array}{l}\text { Hydraulic Fracturing Fluid + Brine } \\
\text { Composition }\end{array}$} \\
\hline Ingredient & $\begin{array}{l}\text { Amount per } \\
\text { Liter }\end{array}$ & Purpose \\
\hline Hydrochloric Acid & $0.634 \mathrm{ml}$ & $\begin{array}{l}\text { Perforation } \\
\text { Cleaner }\end{array}$ \\
\hline Ammonium Persulfate & $0.200 \mathrm{~g}$ & Oxidative Breaker \\
\hline Petroleum distillates & $1.149 \mathrm{ml}$ & $\begin{array}{l}\text { Gelling agent, } \\
\text { Friction Reducer }\end{array}$ \\
\hline Choline Chloride & $1.060 \mathrm{~g}$ & Clay Stabilizer \\
\hline Glutaraldehyde & $0.343 \mathrm{ml}$ & Biocide \\
\hline Potassium Hydroxide & $0.0357 \mathrm{ml}$ & $\mathrm{pH}$ adjuster \\
\hline Potassium Carbonate & $0.240 \mathrm{~g}$ & $\mathrm{pH}$ adjuster \\
\hline Ethylene Glycol & $0.0222 \mathrm{ml}$ & Scale Inhibitor \\
\hline Citric Acid & $0.0336 \mathrm{~g}$ & Iron Control \\
\hline Boric Acid & $0.0200 \mathrm{~g}$ & Cross Linker \\
\hline Ethanolamine & $0.0138 \mathrm{ml}$ & Cross Linker \\
\hline Cinnamaldehyde & $0.0012 \mathrm{ml}$ & Corrosion Inhibitor \\
\hline Barium Chloride Dehydrate & $0.464 \mathrm{~g}$ & Brine \\
\hline Potassium Chloride & $0.416 \mathrm{~g}$ & Brine \\
\hline $\begin{array}{l}\text { Strontium Chloride } \\
\text { Hexahydrate }\end{array}$ & $1.360 \mathrm{~g}$ & Brine \\
\hline Ammonium Chloride & $0.160 \mathrm{~g}$ & Brine \\
\hline Sodium Bromide & $0.180 \mathrm{~g}$ & Brine \\
\hline $\begin{array}{l}\text { Calcium Chloride } \\
\text { Dehydrate }\end{array}$ & $7.400 \mathrm{~g}$ & Brine \\
\hline $\begin{array}{l}\text { Magnesium Chloride } \\
\text { Sesquihydrate }\end{array}$ & $1.900 \mathrm{~g}$ & Brine \\
\hline Sodium Chloride & $16.700 \mathrm{~g}$ & Brine \\
\hline Sodium Sulfate & $0.00029 \mathrm{~g}$ & Brine \\
\hline Sodium Bicarbonate & $0.150 \mathrm{~g}$ & Brine \\
\hline
\end{tabular}

Table 2 - Fracturing fluid additives and brine salts used to make the synthetic fracturing fluid mixture used in reactions. 


\begin{tabular}{|c|c|c|c|c|c|c|c|c|c|c|}
\hline $\begin{array}{c}\text { Sampled } \\
\text { Reaction }\end{array}$ & $\mathbf{p H}$ & $\begin{array}{c}\mathbf{S O}_{4} \\
(\mathbf{m g} / \mathbf{L})\end{array}$ & $\begin{array}{c}\mathbf{B a} \\
(\mathbf{m g} / \mathbf{L})\end{array}$ & $\begin{array}{c}\mathbf{F e} \\
(\mathbf{m g} / \mathbf{L}\end{array}$ & $\begin{array}{c}\mathrm{Al} \\
(\mathbf{m g} / \mathbf{L})\end{array}$ & $\begin{array}{c}\text { As } \\
(\mathbf{u g} / \mathbf{L})\end{array}$ & $\begin{array}{c}\mathbf{C d} \\
(\mathbf{u g} / \mathbf{L})\end{array}$ & $\begin{array}{c}\mathbf{U} \\
(\mathbf{u g} / \mathbf{L})\end{array}$ & $\begin{array}{c}\text { Citrate } \\
(\mathbf{m g} / \mathbf{L})\end{array}$ & $\begin{array}{c}\mathbf{D I C} \\
(\mathbf{m g} / \mathbf{L})\end{array}$ \\
\hline SH-HFF & 6.2 & 162.45 & 3.2 & 0.2 & $<0.025$ & 23.2 & 9.15 & $<0.155$ & 1.97 & 12.59 \\
\hline HFF & 2.3 & 6.27 & 52.29 & 36.42 & 0.12 & 5.06 & 6.43 & 0.155 & 1.1 & 1.463 \\
\hline SH-HFF (-CO3) & 1.8 & 137.63 & 3.36 & 162.4 & 29.84 & 243.3 & 79.7 & 95.9 & 20.44 & 5.749 \\
\hline Unreacted HFF & 2.2 & 168.38 & 306 & $\begin{array}{c}\text { None } \\
\text { Added }\end{array}$ & $\begin{array}{c}\text { None } \\
\text { Added }\end{array}$ & $\begin{array}{c}\text { None } \\
\text { Added }\end{array}$ & $\begin{array}{c}\text { None } \\
\text { Added }\end{array}$ & $\begin{array}{c}\text { None } \\
\text { Added }\end{array}$ & 33 & $\begin{array}{c}\text { No } \\
\text { Data }\end{array}$ \\
\hline
\end{tabular}

Table 3- Tabulated $\mathrm{pH}, \mathrm{IC}$ and ICP-MS fluid chemistry results for each reaction and unreacted fracturing fluid.

*- Calculated from added ingredients

\begin{tabular}{|l|c|c|c|c|c|}
\hline Compound & Benzene (ug/L) & Ethylbenzene (ug/L) & $\mathbf{m , p}-\mathbf{X y l e n e}(\mathbf{u g} / \mathbf{L})$ & $\mathbf{o - X y l e n e ~ ( u g / L )}$ & Toluene (ug/L) \\
\hline SH-HFF & 1.01 & 0.95 & 12 & 4.2 & 4.97 \\
\hline HFF & $\mathrm{ND}$ & Non-Detect & 0.92 & Non-Detect & Non-Detect \\
\hline SH-HFF (-CO3) & 0.35 & Non-Detect & 1.25 & 0.53 & Non-Detect \\
\hline Limit of Detection & 0.0790 & 0.2080 & 0.3700 & 0.1120 & 0.1020 \\
\hline Quantification Limit & 0.5000 & 2.0000 & 1.0000 & 1.0000 & 0.5000 \\
\hline
\end{tabular}

Table 4 - BTEX in solution from GC-MS analysis with detection and quantification limits.

* - Qualitative data below limit of quantification 